\title{
Clinical Practice Guidance and Education in Ultrasound: Evidence and experience are two sides of one coin!
}

\author{
Leitlinien für die klinische Praxis und Ausbildung im Ultraschall: Evidenz und Erfahrung \\ sind die zwei Seiten derselben Medaille!
}

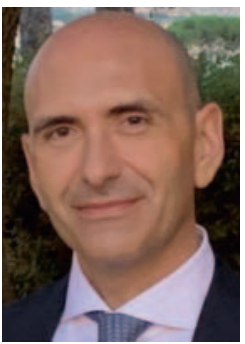

Vito Cantisani

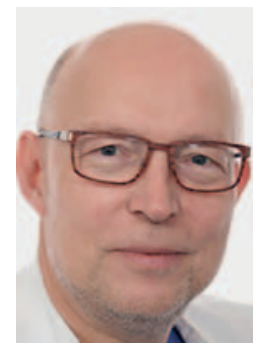

Christian Jenssen

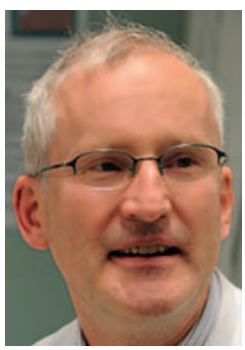

Christoph Frank Dietrich

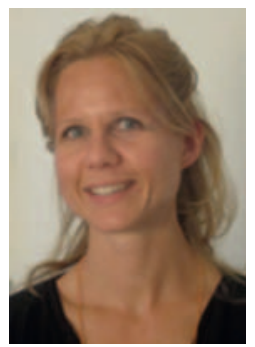

Caroline Ewertsen

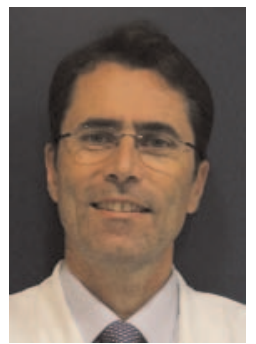

Fabio Piscaglia
Correspondence

Dr. Vito Cantisani

Department of Radiology, Sapienza-University of Rome, Viale Regina Elena 324, 00161 Rome, Italy

Tel.: +39/3471743947

Fax: +39/064455602

vito.cantisani@uniroma1.it
Bibliography

Ultraschall in Med 2022; 43: 7-11

DOI 10.1055/a-1699-7473

ISSN $0172-4614$

(C) 2022. Thieme. All rights reserved.

Georg Thieme Verlag KG, Rüdigerstraße 14,

70469 Stuttgart, Germany
In this issue of the Journal a new set of European Federation of Societies for Ultrasound in Medicine and Biology (EFSUMB) guidelines is reported [1]. Some years ago it was discussed how guidelines are prepared, but things are continuously changing [2, 3].

Initially, guidelines were mainly based on expert opinions due to the limited availability of high-quality evidence. Within recent years the paradigm that guidelines should be based on evidence has prevailed. However, if evidence was not available, recommendations continued to be based on expert opinions, which were not necessarily correct nor objective. The differences in the methodology of clinical guidelines are sometimes considerable, without this always being apparent to the reader at first glance. This concerns in particular the formulation of clinical key questions guiding the systematic retrieval of evidence, its evaluation, the process of transforming evidence into recommendations, and the rules for reaching agreement in the guideline panel on conflicting conclusions from the research evidence. Other issues that affect the trustability of guidelines are the constitution of expert panels, the handling of potential conflicts of interest, the funding of guidelines, the voting and update rules. Therefore, several academic institutions have proposed standards for "trustworthy clinical guidelines" as well as instruments for their assessment [4-8]. Since different systems were used to grade the evidence, as it was the case also in previous EFSUMB guidelines, the international Grading of Recommendations Assessment, Development and Evaluation (short GRADE) working group was gathered in order to design consistent and widely accepted criteria [9]. The GRADE approach, last updated in 2016, aims at an unification of the systems, reducing unnecessary confusion arising from multiple systems for grading evidence and recommendations. Moreover, rules were established to weigh the benefits and risks of recommended care options. Many guidelines have adopted the new modality since then, including some EFSUMB guidelines [10-12]. Aiming at improving the "trustworthiness" of EFSUMB guidelines, EFSUMB published new rules for the development of guidelines and other policy documents in 2019 [3], which have been adopted also by WFUMB [13]. More recently, the PICO process [14] in conjunction with GRADE is more widely used. PICO is a mnemonic used to describe the four elements of a good clinical key question: $\mathrm{P}=$ Population/Patient/Problem - How would I describe the problem or a group of patients like mine? I = Intervention - What main intervention, prognostic factor or exposure am I considering? $\mathrm{C}=$ Comparison - Is there an alternative to compare with the intervention? $\mathrm{O}=$ Outcome - What do I hope to accomplish, measure, improve or affect? The adoption of these systems is obviously a benefit but also encounters limitations. Using this methodology some guidelines (e.g., that on the treatment of hepatocellular carcinoma published by the American Association for the Study of Liver Diseases) only addressed a few selected clinical key questions and excluded issues when prospective randomized trials were not available [15]. Even though this process certainly facilitates the delivery of answers based on strong 
evidence with a clear recommendation, the clinical key questions are often difficult to formulate in a way that matches the daily clinical practice. Moreover, they may leave some clinical situations that are not fully covered, which may differ from more narrative guidelines (for instance that on the same topic of treatment of hepatocellular cancer as the one mentioned before, but from another scientific society, the European Association for the Study of the Liver [16]. The challenges by adopting the GRADE and PICO systems are particularly visible in fields like surgery or radiology/ imaging, where randomized controlled studies are more difficult to perform compared with pharmacological studies. This issue has lead some authors to wonder whether randomized controlled trials are always necessary to establish new or modify already existing recommendations in the field of surgery [17]. We believe that radiology/imaging may have similar challenges as surgery. In keeping with these questions and with the fact that many relevant clinical issues are not well incorporated into PICO questions or will hardly be supported by the strongest evidence, some new proposals have been brought forward by Spellberg et al. [18]. These authors recommend that "clinical guideline recommendationsw hich create care standardss - hould be based only on systematic reviews of replicated, prospective, controlled trials or similar high-quality, hypothesis-confirming data. Recommendations should not be made for questions lacking hypothesis-confirming data". This would most likely result in ultrasound guidelines containing significantly fewer recommendations and leaving only the strongest ones. Despite the lack of high-quality evidence, ultrasound practitioners expect guidelines to provide well considered answers to unsettled questions arising from common clinical situations. How to deal then with the many situations lacking hypothesis-confirming data? Spellberg et al. suggest this solution: "These questions should instead be answered in the form of distinctly marked Clinical Review or Consensus Opinion sections. Rather than proscribing care via 'recommendations', these Clinical Review or Consensus Opinion sections should summarize the available hypothesis generating data to discuss various care options that can be individualized for patients across diverse care settings. Disagreements in literature or among experts should be transparently highlighted, and the pros and cons of each choice should be described so that diverse practitioners can decide how best to apply them to their patients" [18]. We endorse these very current views, which also highlight the need for stronger education in ultrasound, provided or endorsed by scientific societies. Such education in ultrasound should therefore also include a sort of Clinical Review of specific ultrasound applications in the future. Overall, there is a growing need for more narrative ultrasound guidelines that provide explanations and advice to empower responsible choice between various care options, rather than rigid precriptions and proscriptions that impede action adopted to specific clinical situations.

The challenges of this relevant role of education and clinical review have already been addressed by EFSUMB. To promote the integration of ultrasound training into the university curricula, EFSUMB $[19,20]$ and the World Federation for Ultrasound in Medicine and Biology (WFUMB) [21, 22] have published policy statements on medical student education in ultrasound. Despite the increasing role of ultrasound, structured ultrasound teaching is only slowly integrated into the curricula of medical schools all over Europe. A previously published EFSUMB questionnaire survey focusing on the implementation of ultrasound education showed that the financial burden and demand for teachers were the major obstacles for the integration of ultrasound into the curricula in universities [23]. To overcome these obstacles implementing e-learning, the use of ultrasound phantoms and simulators or the "Teach-the-teacher" curricula has been suggested. In the present EJU issue, Hofer et al. investigated whether and how the extent of an ultrasound instructor's clinical background, comparing clinicians/residents versus student instructors may influence the resulting level of hands-on ultrasound competency achieved by clinicians after three days of comprehensive ultrasound courses in abdominal and emergency ultrasound - as measured by the results of the participants' OSCE (objective structured clinical examination) examination scores - and as indicated by evaluation scores gathered from course participants [24]. They concluded that student-peer instructors can be as effective as clinically experienced staff instructors in teaching hands-on ultrasound competencies, based on prior comprehensive didactic skills training. However, it should be underlined that this study should be followed up by assessment of the retention of the ultrasound skills and on how the educational process should be.

In conclusion, we are in a necessary and exciting process trying to increase the trustworthiness of ultrasound guidelines and the quality of curricular ultrasound education for medical students. Together with its member societies, EFSUMB will continue to follow this path, attracting the acceptance, ingenuity and support of universities and our academic partners in Europe and beyond. Performing high-quality clinical ultrasound needs reliable guidance. Therefore, Clinical Practice Guidelines should honestly and transparently distinguish between evidence-based recommendations and thoughtful expert advice, when hypothesis-conforming evidence is still lacking. Equally indispensable is practical training, which should be started already during medical school. Evidence and experience are two sides of the same coin, and only together they form the stable currency of clinical ultrasound expertise.

\section{Leitlinien für die klinische Praxis und Ausbildung im Ultraschall: Evidenz und Erfahrung sind die zwei Seiten derselben Medaille!}

In dieser Ausgabe der Zeitschrift wird über eine Reihe neuer Leitlinien der „European Federation of Societies for Ultrasound in Medicine and Biology“ (EFSUMB) berichtet [1]. Vor einigen Jahren wurde erörtert, wie Leitlinien erstellt werden; aber diese Dinge sind ständig in Fluss [2, 3].

Ursprünglich fußten Leitlinien aufgrund der geringen Verfügbarkeit qualitativ guter Evidenz ganz überwiegend auf reiner Expertenmeinung. In den letzten Jahren hat sich jedoch das Paradigma durchgesetzt, dass Leitlinien grundsätzlich evidenzbasiert sein sollten. Wenn dennoch keine belastbare Evidenz verfügbar war, gründeten sich die Empfehlungen weiter auf Expertenmei- 
nungen, die nicht unbedingt richtig oder objektiv sein mussten. Teilweise gibt es bei klinischen Leitlinien erhebliche methodische Unterschiede, ohne dass diese für den Leser auf den ersten Blick ersichtlich sind. Dies betrifft insbesondere die Formulierung klinischer Schlüsselfragen, von der systematische Evidenzrecherche und deren Bewertung abhängen, die Umsetzung der Evidenz in Empfehlungen sowie die Regeln, nach denen im Falle von kontroversen Interpretationen der Evidenz in der Leitlinienkommission entschieden wird. Weitere Fragen in Bezug auf die Vertrauenswürdigkeit von Leitlinien sind die Zusammensetzung der Expertengremien, der Umgang mit potenziellen Interessenkonflikten, die Finanzierung der Leitlinien sowie die Abstimmungs- und Aktualisierungsregeln. Daher haben mehrere akademische Institutionen Standards für „vertrauenswürdige klinische Leitlinien“ und Instrumente zu deren Bewertung vorgeschlagen [4-8]. Da zur Bewertung der Evidenz unterschiedliche Systeme verwendet wurden, wie dies auch bei früheren EFSUMB-Leitlinien der Fall war, wurde die internationale Arbeitsgruppe "Grading of Recommendations Assessment, Development and Evaluation“ (kurz GRADE) ins Leben gerufen, um einheitliche und allgemein akzeptierte Kriterien zu entwickeln [9]. Der zuletzt 2016 aktualisierte GRADEAnsatz zielt auf eine Vereinheitlichung der Systeme ab, um unnötige Verwirrung zu vermeiden, die sich aus den zahlreichen Systemen zur Graduierung von Evidenz und Empfehlungen ergibt. Darüber hinaus wurden Regeln aufgestellt, um Nutzen und Risiken der empfohlenen Behandlungsoptionen abzuwägen. Seitdem haben viele Leitlinien diese neue Herangehensweise übernommen, darunter auch einige EFSUMB-Leitlinien [10-12]. Mit dem Ziel, die „Vertrauenswürdigkeit“ der EFSUMB-Leitlinien zu verbessern, veröffentlichte die EFSUMB 2019 neue Regeln für die Entwicklung von Leitlinien und anderen Grundsatzdokumenten [3], die auch von der WFUMB übernommen wurden [13]. In jüngerer Zeit wird das PICO-Schema [14] in Verbindung mit GRADE häufiger verwendet. PICO ist ein Akronym und steht für 4 Kriterien, mit denen eine gute klinische Fragestellung beschrieben werden kann: $\mathrm{P}=$ Population/Patient/Problem - Wie beschreibe ich das Problem oder die Gruppe von Patienten in meinem Fall? I = Intervention - Welche Hauptintervention, welchen prognostischen Faktor oder welche Exposition ziehe ich in Betracht? $\mathrm{C}=$ „Comparison“ (Vergleich) - gibt es eine Alternative, die mit der Intervention verglichen werden kann? O= „Outcome“ (Zielgröße) - Was möchte ich erreichen, messen, verbessern oder beeinflussen? Die Anwendung dieser Systeme ist von Vorteil, stößt aber auch an ihre Grenzen. So wurden in einigen Leitlinien (z. B. in der von der „American Association for the Study of Liver Diseases“ veröffentlichten Leitlinie zur Behandlung des Leberzellkarzinoms) nur einige ausgewählte klinische Fragestellungen behandelt und Themen ausgeklammert, für die keine prospektiven randomisierten Studien verfügbar waren [15]. Auch wenn dieses Verfahren sicherlich die Bereitstellung evidenzbasierter Antworten mit einer klaren Empfehlung erleichtert, sind die klinisch relevanten Fragestellungen mit Bezug zur täglichen Praxis oft schwer zu formulieren. Darüber hinaus kann es vorkommen, dass einige klinische Situationen nicht vollständig abgedeckt werden - im Unterschied zu eher narrativen Leitlinien beispielsweise denen einer anderen Fachgesellschaft, nämlich der European Association for the Study of the Liver, zum gleichen Gegenstand der Behandlung des hepatozellulären Karzinoms [16]. Die Herausforderungen bei der Übernahme der GRADE- und PICO-Systeme werden besonders in Fachbereichen wie der Chirurgie oder Radiologie/Bildgebung deutlich, in denen randomisierte kontrollierte Studien, im Vergleich zu pharmakologischen Studien, schwieriger durchzuführen sind. Dieses Problem hat einige Verfasser zu der Frage veranlasst, ob randomisierte kontrollierte Studien immer notwendig sind, um auf dem Gebiet der Chirurgie neue Empfehlungen zu erstellen oder bereits bestehende Empfehlungen zu ändern [17]. Wir glauben, dass die Radiologie/Bildgebung vor ähnlichen Herausforderungen steht wie die Chirurgie. Im Einklang mit diesen Fragen und der Tatsache, dass viele relevante klinische Themen nicht gut in PICO-Fragen integriert sind oder kaum durch die stärkste Evidenz gestützt werden, wurden einige neue Vorschläge von Spellberg et al. zur Diskussion gestellt [18]. Die Autoren empfehlen, dass „klinische Leitlinienempfehlungen, die Versorgungsstandards schaffen, nur auf systematische Übersichtsarbeiten über reproduzierbare, prospektive, kontrollierte Studien oder auf ähnlich hochwertigen, hypothesebestätigenden Daten beruhen sollten. Für Fragestellungen, für die keine hypothesebestätigenden Ergebnisse vorliegen, sollten keine Empfehlungen ausgesprochen werden“. Dies würde höchstwahrscheinlich dazu führen, dass die Ultraschall-Leitlinien deutlich weniger Empfehlungen enthalten und nur die stärksten Empfehlungen übrigbleiben. Trotz des Mangels an qualitativ hochwertiger Evidenz erwarten die Ultraschallmediziner, dass die Leitlinien gut durchdachte Antworten auf ungeklärte Fragen geben, die sich aus häufigen klinischen Situationen ergeben. Wie also mit den vielen Situationen umgehen, für die es keine hypothesebestätigenden Daten gibt? Spellberg et al. schlagen diese Lösung vor: „Diese Fragen sollten stattdessen in Abschnitten, die eindeutig als ,Clinical Review oder ,Consensus Opinion' gekennzeichnet sind, beantwortet werden. Anstatt die Behandlung durch ,Empfehlungen ' vorzuschreiben, sollen diese Abschnitte mit klinischen Übersichten oder Konsensmeinungen eine Zusammenfassung der verfügbaren, hypothesebestätigenden Daten enthalten, um verschiedene Behandlungsoptionen zu erörtern, die für Patienten in unterschiedlichen Versorgungssituationen individuell angepasst werden können. Unterschiedliche Meinungen in der Literatur oder unter Experten sollten transparent aufgezeigt und die Vor- und Nachteile jeder Option beschrieben werden, damit die unterschiedlichen Ärzte entscheiden können, wie sie diese am besten auf ihre Patienten anwenden ' [18]. Wir schließen uns diesen sehr aktuellen Ansichten an, die auch die Notwendigkeit einer besseren Ultraschall-Ausbildung unterstreichen, die von wissenschaftlichen Gesellschaften angeboten oder unterstützt wird. Eine derartige Ausbildung im Ultraschall sollte daher in Zukunft auch eine Form der klinischen Review von spezifischen sonografischen Anwendungen beinhalten. Insgesamt besteht ein zunehmender Bedarf an eher narrativen Ultraschall-Leitlinien, die Erklärungen und Ratschläge bieten, um eine verantwortungsvolle Wahl zwischen verschiedenen Behandlungsoptionen zu ermöglichen, anstatt starrer Vorschriften, die ein auf spezifische klinische Situationen abgestimmtes Handeln verhindern.

Die EFSUMB hat sich bereits mit den Herausforderungen befasst, die mit dieser wichtigen Rolle von Ausbildung und klinischer Review einhergehen. Um die Integration der Ultraschallausbil- 
dung in die universitären Curricula zu fördern, haben die EFSUMB $[19,20]$ und die „World Federation for Ultrasound in Medicine and Biology“ (WFUMB) [21, 22] Grundsatzerklärungen zur UltraschallAusbildung von Medizinstudenten veröffentlicht. Trotz der zunehmenden Bedeutung der Sonografie wird der strukturierte Ultraschallunterricht nur langsam in die Lehrpläne der medizinischen Fakultäten in ganz Europa integriert. Eine bereits veröffentlichte Fragebogenerhebung der EFSUMB, die sich auf die Umsetzung der Ultraschall-Ausbildung konzentrierte, zeigte, dass der finanzielle Aufwand und der Bedarf an Lehrkräften die größten Hindernisse für die Integration des Ultraschalls in die Curricula der Universitäten waren [23]. Zur Überwindung dieser Hindernisse wurden die Einführung von E-Learning, die Verwendung von Ultraschallphantomen und -simulatoren oder „Teach-the-teacher“-Lehrpläne vorgeschlagen. In der vorliegenden EJU-Ausgabe untersuchten Hofer et al., ob und inwiefern der klinische Hintergrund eines Ultraschallausbilders (Klinik-/Assistenzärzte verglichen mit studentischen Ausbildern) Einfluss hat auf die praktische Ultraschallkompetenz von Klinikärzten nach Absolvierung eines 3-tägigen umfassenden Ultraschallkurses im Abdomen- und Notfall-Ultraschall. Ermittelt wurde dies anhand der Ergebnisse der OSCE- Prüfungs-Scores („Objective Structured Clinical Examination") der Teilnehmenden und anhand der Bewertungs-Scores von den Kursteilnehmern [24]. Die Autoren kamen zu dem Schluss, dass studentische Tutoren bei der Vermittlung praktischer Ultraschallkompetenzen ebenso effektiv sein können wie klinisch erfahrene Dozenten, die zuvor eine umfassende didaktische Ausbildung absolviert haben. Es muss jedoch hervorgehoben werden, dass es im Anschluss an diese Studie noch weiter zu untersuchen gilt, ob die erworbenen Ultraschallfertigkeiten dauerhaft erhalten bleiben und wie der Trainingsprozess optimal gestaltet werden sollte.

Zusammenfassend lässt sich sagen, dass wir uns in einem notwendigen und spannenden Prozess befinden, der die Vertrauenswürdigkeit von Ultraschall-Leitlinien und die Qualität der Curricula in der Ultraschall-Ausbildung für Medizinstudenten verbessern soll. Gemeinsam mit ihren Mitgliedsgesellschaften wird die EFSUMB diesen Weg weiterverfolgen und dabei um die Akzeptanz, den Einfallsreichtum und die Unterstützung der Universitäten und unserer akademischen Partner in Europa und darüber hinaus zu werben. Qualitativ hochwertige klinische UltraschallUntersuchungen erfordern zuverlässige Handlungsempfehlungen. Daher sollten Leitlinien für die klinische Praxis ehrlich und transparent zwischen evidenzbasierten Empfehlungen und wohlüberlegten Expertenratschlägen unterscheiden, wenn keine hypothesenbestätigte Evidenz vorliegt. Ebenso unverzichtbar ist die praktische Ausbildung, die bereits während des Medizinstudiums begonnen werden sollte. Evidenz und Erfahrung sind 2 Seiten derselben Medaille, und nur zusammen bilden sie die stabile Währung der klinischen Ultraschallexpertise.

\section{Conflict of Interest}

Vito Cantisani declares SIUMB, SIRM, ESR, EFSUMB and WFUMB membership and lectured for Bracco, Samsung, Canon.

Fabio Piscaglia declares SIUMB, EFSUMB and WFUMB membership, member of the Governing Board of the International Contrast Ultrasound
Society and collaborations with Esaote (research contract and speaker bureau honoraria), Bayer (speaker bureau and advisory board), Bracco (speaker bureau), Samsung (speaker bureau), Astrazeneca (advisory board), EISAI (speaker bureau and advisory board), MSD (speaker bureau and advisory board), IPSEN (speaker bureau), Tiziana Life Sciences (advisory board) and Roche (advisory board).

Christian Jenssen declares DEGUM, EFSUMB and WFUMB membership and lectured for GE.

Christoph Frank Dietrich declares EFSUMB and WFUMB membership. Caroline Ewertsen declares EFSUMB and WFUMB membership.

\section{References}

[1] Fodor D, Rodriguez-Garcia SC, Cantisani V et al. The EFSUMB Guidelines and Recommendations for Musculoskeletal Ultrasound - Part I: Extraarticular Pathologies. Ultraschall in Med 2022; 43

[2] Ingravallo F, Dietrich CF, Gilja OH et al. Guidelines, clinical practice recommendations, position papers and consensus statements: definition, preparation, role and application. Ultraschall in Med 2014; 35: 395-399

[3] Jenssen C, Gilja OH, Serra AL et al. European Federation of Societies for Ultrasound in Medicine and Biology (EFSUMB) Policy Document Development Strategy - Clinical Practice Guidelines, Position Statements and Technological Reviews. Ultrasound Int Open 2019; 5: E2-E10

[4] Graham R, Mancher M, Miller Wolman D et al. Clinical Practice Guidelines We Can Trust. Washington, DC: National Academies Press (US); 2011

[5] Qaseem A, Forland F, Macbeth F et al. Guidelines International Network: toward international standards for clinical practice guidelines. Ann Intern Med 2012; 156: 525-531

[6] Schunemann HJ, Wiercioch W, Etxeandia I et al. Guidelines 2.0: systematic development of a comprehensive checklist for a successful guideline enterprise. CMAJ 2014; 186: E123-E142

[7] Semlitsch T, Blank WA, Kopp IB et al. Evaluating Guidelines: A Review of Key Quality Criteria. Dtsch Arztebl Int 2015; 112: 471-478

[8] Brignardello-Petersen R, Carrasco-Labra A, Guyatt GH. How to Interpret and Use a Clinical Practice Guideline or Recommendation: Users' Guides to the Medical Literature. JAMA 2021; 326: 1516-1523

[9] Grading of Recommendations Assessment, Development and Evaluation (short GRADE) working group. 2021 https://www.gradeworkinggroup.org/

[10] Dietrich CF, Bamber ], Berzigotti A et al. EFSUMB Guidelines and Recommendations on the Clinical Use of Liver Ultrasound Elastography, Update 2017 (Long Version). Ultraschall in Med 2017; 38: e16-e47

[11] Sidhu PS, Cantisani V, Dietrich CF et al. The EFSUMB Guidelines and Recommendations for the Clinical Practice of Contrast-Enhanced Ultrasound (CEUS) in Non-Hepatic Applications: Update 2017 (Long Version). Ultraschall in Med 2018; 39: e2-e44

[12] Dietrich CF, Nolsoe CP, Barr RG et al. Guidelines and Good Clinical Practice Recommendations for Contrast-Enhanced Ultrasound (CEUS) in the Liver-Update 2020 WFUMB in Cooperation with EFSUMB, AFSUMB, AIUM, and FLAUS. Ultrasound Med Biol 2020; 46: 2579-2604

[13] Dietrich CF, Abramowicz JS, Chammas MC et al. World Federation for Ultrasound in Medicine and Biology (WFUMB) Policy Document Development Strategy - Clinical Practice Guidelines, Position Statements and Technological Reviews (on behalf of the WFUMB publication committee and Executive Bureau). Ultrasound Med Biol 2021; 47: 2779-2781

[14] PICO. https://en.wikipedia.org/wiki/PICO_process

[15] Heimbach JK, Kulik LM, Finn RS et al. AASLD guidelines for the treatment of hepatocellular carcinoma. Hepatology 2018; 67: 358-380

[16] European Association for the Study of the Liver. Electronic address eee, European Association for the Study of the L. EASL Clinical Practice Guidelines: Management of hepatocellular carcinoma. J Hepatol 2018; 69: 182-236 
[17] Ravaioli M, Piscaglia F, Cillo U et al. Is the Strongest Level of Medical Evidence Always Required for Guidelines Recommendations? Liver Cancer 2021; 10: 394-395

[18] Spellberg B, Wright WF, Shaneyfelt T et al. The Future of Medical Guidelines: Standardizing Clinical Care With the Humility of Uncertainty. Ann Intern Med 2021; 174: 1740-1742

[19] Cantisani V, Dietrich CF, Badea R et al. EFSUMB statement on medical student education in ultrasound [short version]. Ultraschall in Med 2016; 37: 100-102

[20] Cantisani V, Dietrich CF, Badea R et al. EFSUMB Statement on Medical Student Education in Ultrasound [long version]. Ultrasound Int Open 2016; 2: E2-E7
[21] Dietrich CF, Hoffmann B, Abramowicz ] et al. Medical Student Ultrasound Education: A WFUMB Position Paper, Part I. Ultrasound Med Biol 2019; 45: 271-281

[22] Hoffmann B, Blaivas M, Abramowicz J et al. Medical Student Ultrasound Education, a WFUMB Position Paper, Part II. A consensus statement of ultrasound societies. Med Ultrason 2020; 22: 220-229

[23] Prosch H, Radzina M, Dietrich CF et al. Ultrasound Curricula of Student Education in Europe: Summary of the Experience. Ultrasound Int Open 2020; 6: E25-E33

[24] Hofer M, Kamper L, Heussen N et al. Influence of Clinical Expertise Between Clinician-Instructors Versus Student-Instructors on the Effectiveness of Ultrasound Courses. 2020. doi:10.1055/a-1176-0622 Online ahead of print. 